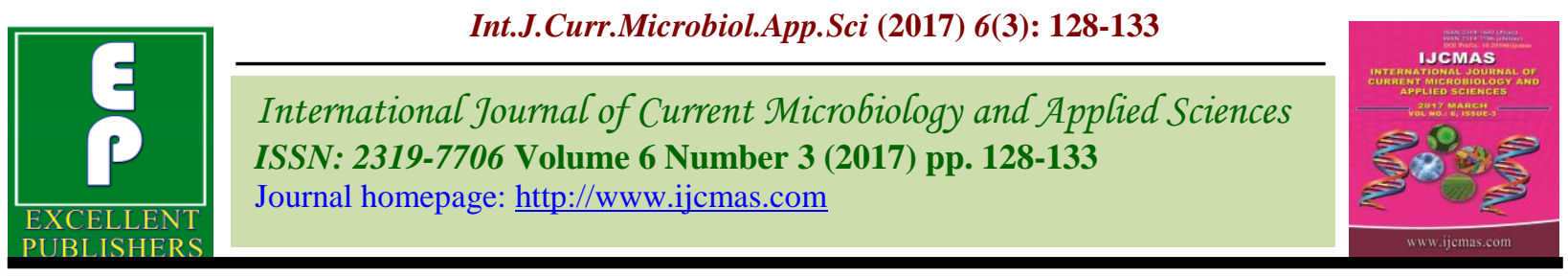

Original Research Article

https://doi.org/10.20546/ijcmas.2017.603.014

\title{
Assessment of Breeding Potential of Ridge Gourd [Luffa acutangula (roxb.) L.] Germplasm for Growth, Yield and Quality Using Diversity $\left(\mathrm{D}^{2}\right)$ Analysis
}

\author{
E. Alli Rani ${ }^{1 *}$, P. Jansirani ${ }^{2}$ and J.R. Kannan Bapu ${ }^{3}$ \\ ${ }^{1}$ Department of Vegetable Crops, Horticulture College and Research Institute, Tamil Nadu \\ Agricultural University, Coimbatore - 641 003, Tamil Nadu, India \\ ${ }^{2}$ Department of Spices and Plantation Crops, Horticulture College and Research Institute, Tamil \\ Nadu Agricultural University, Periyakulam - 625 604, Tamil Nadu, India \\ ${ }^{3}$ Department of Pulses, TNAU, Coimbatore - 641003, India \\ *Corresponding author
}

\section{A B S T R A C T}

\section{Keywords}

Diversity analysis, Genotypes, Luffa acutangula.

Article Info

Accepted:

08 February 2017

Available Online:

10 March 2017
An investigation on evaluation of ridge gourd germplasm was carried out at College Orchard, Department of Vegetable Crops, Horticulture College and Research Institute, TNAU, Coimbatore. Totally thirty five ridge gourd genotypes were grouped into five clusters based on $\mathrm{D}^{2}$ values, which exhibited no association between geographical and genetic divergence. The intra-cluster distance was maximum for cluster III (167.41) and minimum for cluster $\mathrm{V}(0)$. The maximum distance at inter-cluster level was between cluster II and cluster V (535.54) followed by clusters III and II (195.34) which may serve as a potential genotypes for hybridization programme. On the basis of mean performance of different clusters, genotypes having better performance for days taken for first female flower appearance, highest female flower number per vine, narrow sex ratio, fruit length, days taken for first harvest, fruit weight, lowest crude fibre content, highest carbohydrate content and protein content were observed in cluster V. Genotypes having vine length, fruit girth, less seeds number per fruit and more hundred seed weight were recorded in cluster II. The genotypes of the cluster III were grouped for high fruit flesh thickness, fruits number per vine and fruit yield per vine which could be utilized as donor parents for respective traits in hybridization programme for enhancing the yield of other accessions grouped in a cluster in $\mathrm{F}_{1} \mathrm{~S}$ and could be fixed by transgressive segregants followed by continued selection in advance generations which may lead to development of high yielding varieties with desired component characters.

\section{Introduction}

Ridge gourd [Luffa acutangula (Roxb.)L.] is one of the important cucurbitaceous vegetables grown commercially throughout India. Being a monoecious and cross pollinated crop, with conspicuous and bunchy flowers, large number of seeds per fruit and wide variability for yield, size and shape of fruit would prompt any breeder to exploit these crop commercially. The present production and productivity of ridge gourd is not sufficient enough to meet the nutritional security of increasing current population. The productivity of ridge gourd varies from season to season and region to region. Thus, there is a need to identify stable varieties which is suitable for particular season and 
location. The expression of yield is the outcome of interaction of several characters. It requires vast genetic studies for substantial improvement in yield and quality. Information on direction and magnitude of association of yield and yield contributing characters is important to exercise selection in a breeding programme (Karuppaiah et al., 2005).

In crop improvement, genetic diversity has been considered as an important factor, which is essential pre-requisite for any breeding programme in order to obtain high yielding progenies. Quantitative measurement of genetic divergence among individuals has enabled the plant breeders to understand the racial affinities and evolutionary pattern in various crop species or cultivated plants as well as in decision making for selection of desirable parents to be involved in hybridization programme (Kumar et al., 1998 and Rameshkumar, 2011). The usefulness of multivariate analysis for study of morphologically complex individual and for measuring the degree of divergence between biological populations has been shown in different fields of research.

To study the genetic diversity and to form core subset for grouping the accessions with similar characteristics into homogenous category, cluster analysis is commonly used. Clustering is used to summarize information on relationships between objects by grouping similar units so that the relationship may be easily understood and communicated. Among several methods of multivariate analysis, Mahalanobis $\mathrm{D}^{2}$ statistics has been shown to be very useful in selecting parents for hybridization which meets the objective of a plant breeder.

The use of Mahalanobis $\mathrm{D}^{2}$ statistics for estimating genetic divergence have been emphasized by many workers (Prasad and Singh, 1997) because it permits precise comparison among all possible pairs of population in any given group effecting actual crosses.

Hence, the nature and magnitude of genetic diversity among thirty five ridge gourd genotypes assembled from different geographical locations was measured through multivariate analysis using Mahalanobis $\mathrm{D}^{2}$ statistics to identify suitable and best genotype for hybridization. Mahalanobis $\mathrm{D}^{2}$ statistics measures the force of differentiation as intra, inter cluster levels and has been used as a powerful tool in quantifying the degree of divergence at genotypic level (Khatun et al., 2010).

\section{Materials and Methods}

An investigation on evaluation of ridge gourd germplasm for yield and quality was carried out at College Orchard, Department of Vegetable Crops, Horticulture College and Research Institute, Tamil Nadu Agricultural University, Coimbatore during 2012-13. The experimental materials comprised of thirty five indigenous genotypes of ridge gourd collected from NBPGR, New Delhi, IIHR, Bangalore, KAU, Thrissur, Karnataka local type and TNAU, Coimbatore. The experiment was laid out in a randomized block design with two replications. Seeds were sown in the field on January 2012. All the recommended agronomic package of practices was followed. The observations were recorded on five randomly selected plants per replication for each genotype on eighteen characters of the study. Analysis of variance for 35 ridge gourd genotypes indicated highly significant variability among them for all the 18 characters, viz., vine length (m), days to first female flower appearance, node number for first female flower appearance, male flowers number per vine, female flowers number per vine, sex ratio, days taken to first harvest, fruit length $(\mathrm{cm})$, fruit girth $(\mathrm{cm})$, fruit weight $(\mathrm{g})$, fruit flesh thickness $(\mathrm{cm})$, fruits number per vine, fruit yield per vine $(\mathrm{kg})$, seed 
number per fruit, hundred seed weight $(\mathrm{g})$, crude fibre $(\mathrm{mg} / 100 \mathrm{~g})$, total carbohydrates $(\mathrm{g} / 100 \mathrm{~g})$ and protein $(\mathrm{g} / 100 \mathrm{~g})$. The analysis of variance indicated that the variability in all the eighteen characters studied found to be significant. Mean across two replications were calculated for each traits and the analysis of variation was carried out. Multivariate analysis was done utilizing Mahalanobis $\mathrm{D}^{2}$ statistic (Mahalanobis, 1936) and genotypes were grouped into different clusters following Tocher's method.

\section{Results and Discussion}

On the basis of $\mathrm{D}^{2}$ values, the 35 genotypes were grouped into five highly divergent clusters (Table 1). The cluster divergence was proved by the high inter-cluster and low intracluster $\mathrm{D}^{2}$ values. Cluster $\mathrm{I}$ was the largest and consisted of twenty genotypes followed by cluster III with ten genotypes. Clusters II and IV with two genotypes each and the cluster $\mathrm{V}$ was solitary with single genotype. The grouping pattern did not show any relationship between genetic divergence and geographic diversity which has been a point of debate in the past.

The perusal of the data in table 1 clearly showed that the genotypes usually did not cluster according to geographical distributions. However, geographic diversity is an important factor as it is not the only one determining the genetic divergence. Similar findings were also reported by Singh and Lal (2000) in pointed gourd, Badade et al., (2001) in bottle gourd and Sanwal et al., (2008) in chow chow. One of the possible reasons for the fact may be that it is very difficult to establish the actual location of origin of a genotype. Crop improvement programmes in the country makes it difficult to maintain the real identity of the free and frequent exchange of genetic material among the genotypes. Moreover, breeding progenies incorporate genes from varied sources, thus losing the basic geographical identity of the genotype The absence of relationship between genetic diversity and geographical distance indicates that forces other than geographical origin, such as exchange of genetic stocks, genetic drift, spontaneous variation, nature and artificial selection are responsible for genetic diversity. It may also be possible that causes for clustering pattern were much influenced by environment and genotype $\mathrm{x}$ environment interaction would also have result in differential gene expression. Another possibility may be that, estimates might not have been sufficient to account for the variability caused by some other traits of physiological or biochemical nature which might have been important in depicting the total genetic diversity in the population. The divergence within the cluster (intra-cluster distance) indicates the divergence among the genotypes falling in the same cluster. On the other hand, inter cluster divergence suggests the distance (divergence) between the genotypes of different clusters.

The intra and inter cluster $\mathrm{D}^{2}$ values among thirty five genotypes presented in table 2 revealed that cluster $\mathrm{V}$ showed minimum intra-cluster $\mathrm{D}^{2}$ value (0). Whereas, maximum intra-cluster $\mathrm{D}^{2}$ value (167.41) was shown by cluster III followed by cluster I (144.54). This was an indicative of the fact that the genotypes included in these clusters were found to be very diverse. Minimum intercluster $\mathrm{D}^{2}$ value was observed between the cluster I and IV (151.54) which indicated the close relationship among the genotypes included in these clusters. Maximum intercluster $\mathrm{D}^{2}$ value was observed between the cluster II and V (535.54) followed by cluster III and II (195.34) which indicated that the genotypes belonging to these groups were genetically most divergent and the genotypes included in these clusters could be used as a parent in hybridization programme to get higher heterotic hybrids from the segregating population. 
Table.1 Clustering pattern of ridge gourd genotypes based on $\mathrm{D}^{2}$ analysis

\begin{tabular}{cccccc}
\hline Clusters & I & II & III & IV & V \\
I & $\mathbf{( 1 4 4 . 5 4 )}$ & 153.16 & 159.99 & 122.79 & 443.92 \\
II & & $\mathbf{( 3 5 . 7 0 )}$ & 195.34 & 128.85 & 535.54 \\
III & & & $\mathbf{( 1 6 7 . 4 1 )}$ & 151.54 & 400.02 \\
IV & & & & $\mathbf{( 1 2 5 . 7 0 )}$ & 449.62 \\
V & & & & & $(\mathbf{0 . 0 0 0 )}$ \\
\hline
\end{tabular}

Table.2 Average intra (bold) and inter cluster $\mathrm{D}^{2}$ values for five clusters in ridge gourd genotypes

\begin{tabular}{ccl}
\hline Clusters & Number of genotypes & \multicolumn{1}{c}{ Name of the genotypes } \\
I & 20 & IC 92660, IC 92685, IC105554, IC 105579, IC 110892, IC \\
& & 196589, IC 339239, IC 385912, IC 392334, Arka Sumeet, Arka \\
& Sujat, Deepthi, Coimbatore Local, Notchimedu Local, UP \\
& & Variety Local (var:100), UA 040, UA 050, SG 020 and 2S 134 \\
II & 2 & K 070 and K 090 \\
III & 10 & SG 030, IC 413592, IC 373361, IC 362481, IC 393014, IC \\
& 2 & 393016, IC 413577, IC 413587, LA 1 and LA 2 \\
IV & 1 & CO 2 and PKM - 1 \\
V & CO 1 \\
\hline
\end{tabular}

Table.3 Cluster mean analysis of ridge gourd germplasm for growth, yield and quality

\begin{tabular}{lccccc}
\hline \multicolumn{1}{c}{ Clusters } & I & II & III & IV & V \\
Characters & & & & & \\
Vine length (m) & 7.33 & 8.10 & 7.56 & 7.44 & 7.62 \\
Days to first female flower appearance & 50.67 & 47.10 & 48.88 & 51.12 & 43.58 \\
Node number for first female flower & 24.63 & 25.32 & 26.35 & 22.50 & 22.50 \\
appearance & & & & & \\
Male flowers number per vine & 488.40 & 482.92 & 489.58 & 514.42 & 408.58 \\
Female flowers number per vine & 49.54 & 50.09 & 48.46 & 42.60 & 61.43 \\
Sex ratio (M/F) & 10.22 & 10.21 & 10.64 & 12.09 & 6.65 \\
Days taken to first harvest & 56.70 & 51.89 & 54.76 & 56.97 & 47.36 \\
Fruit length (cm) & 33.05 & 32.74 & 34.14 & 30.59 & 47.55 \\
Fruit girth (cm) & 15.70 & 17.57 & 14.66 & 17.27 & 13.44 \\
Fruit weight (g) & 227.35 & 185.92 & 247.11 & 223.40 & 381.25 \\
Fruit flesh thickness (cm) & 1.23 & 1.16 & 1.24 & 1.15 & 1.17 \\
Fruits number per vine & 8.93 & 5.57 & 9.08 & 8.11 & 8.50 \\
Fruit yield per vine (kg) & 5.34 & 4.21 & 6.07 & 3.80 & 4.07 \\
Seed number per fruit & 160.61 & 115.83 & 166.49 & 149.75 & 120.43 \\
Hundred seed weight (g) & 13.76 & 15.94 & 13.32 & 11.90 & 11.25 \\
Crude fibre (mg per 100 gram) & 2.65 & 2.33 & 2.49 & 3.08 & 1.92 \\
Total carbohydrates content (g per 100 gram) & 0.34 & 0.24 & 0.31 & 0.35 & 0.48 \\
Protein (g per 100 gram) & 0.35 & 0.38 & 0.35 & 0.33 & 0.33 \\
\hline
\end{tabular}


Fig.1 Cluster mean analysis of ridge gourd genotypes for fruit yield per vine Fruit yield per vine $(\mathrm{kg})$

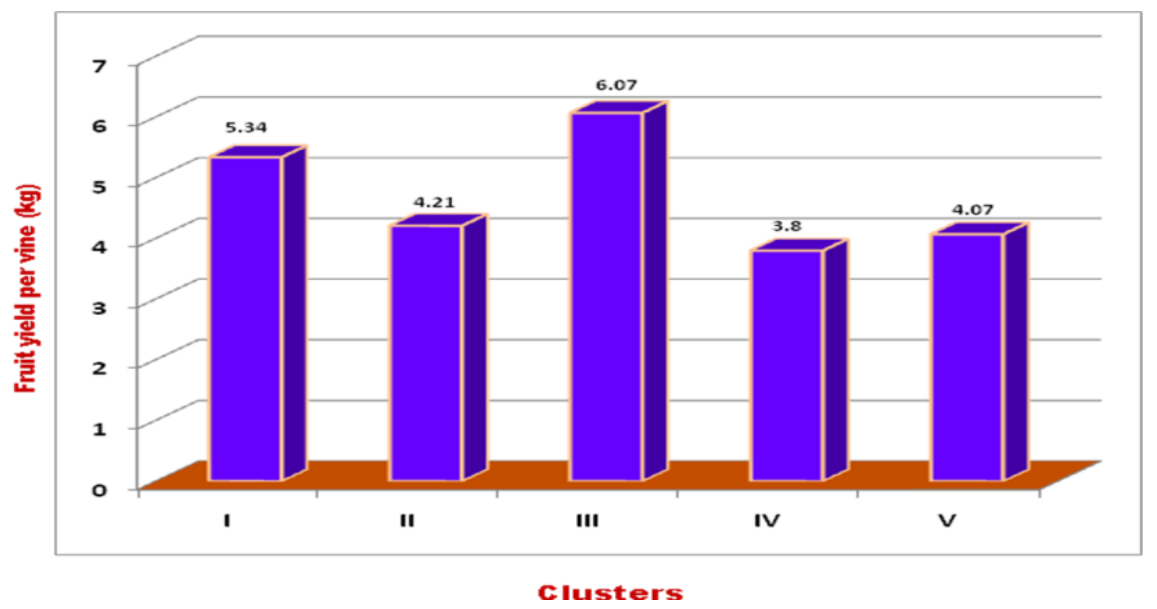

Several authors also reported profound diversity in the germplasm of ridge gourd by assessing genetic divergence on the basis of quantitative traits following Mahalanobis $\mathrm{D}^{2}$ statistics (Sanwal et al., (2008) in chow chow and Reshmi and Sreelathakumary (2011) in ash gourd) which suggested that crossing the genotypes could have resulted in higher average yield and higher inter cluster distance would have also led to broad spectrum of variability in segregating generations.

Overall inter cluster distances were found to be much higher than that of intra cluster distances, indicating that homogeneous and heterogeneous nature of the genotypes within and between the clusters. These results of the present study were in conformity to the findings of Dora et al., (2003) in pointed gourd, Singh et al., (2008) in ridge gourd and Deepa Devi and Mariappan (2013) in snake gourd.

The cluster mean of thirty five ridge gourd genotypes (Table 3) showed that the mean value of clusters varied in magnitude for all the eighteen characters. Genotypes in Cluster V registered the highest cluster mean value for lesser days taken to first female flower appearance (43.58), less node number for first female flower appearance (22.50), less male flowers number per vine (408.58), more female flowers number per vine (61.43), sex ratio
(6.65), lesser days taken to first harvest (47.36), fruit length $(47.55 \mathrm{~cm})$, fruit weight $(381.25 \mathrm{~g})$, less crude fibre $(1.92 \mathrm{mg}$ per $100 \mathrm{~g})$, more total carbohydrate content $(0.48 \mathrm{~g}$ per $100 \mathrm{~g})$ and protein $(0.33 \mathrm{~g}$ per $100 \mathrm{~g})$. The genotypes from the cluster III was found to have more values of fruit flesh thickness $(1.24 \mathrm{~cm})$, fruits number per vine $(9.08)$ and fruit yield vine $(6.07 \mathrm{~kg})$ (Fig. 1). The cluster I was found to record the more fruit girth $(15.70 \mathrm{~cm})$ and less seed number per fruit (160.61). The higher cluster mean values in cluster II was observed for higher values of vine length $(8.10 \mathrm{~m})$ and hundred seed weight (15.94). The cluster IV registered the lesser value for first female flower appearance (22.50). These results of the present study were in conformity to the findings of Khatun et al., (2010) in snake gourd and Singh et al., (2013) in bitter gourd.

It is concluded that in a plant breeding programme aimed at crop improvement, the choice of parents is quite important and only component character of yield should be taken into account for selecting genetically divergent parents. It can be utilized as donor parent for enhancing the yield of other accessions grouped in a cluster in $F_{1} s$ and can be fixed by selecting transgressive segregants followed by continued selection in advance generations which may lead to development of high yielding varieties with desired component characters. The 
genotypes of highly divergent cluster may also be utilized in a breeding programme for development of high yielding varieties with desirable attribute and can also be utilized in heterosis breeding programme for development of $F_{1}$ hybrids with superior yield and quality characters. In this study, the genotypes from the clusters V, III and I scored the highest mean values for growth, yield and quality attributing traits. The inferences drawn from inter-cluster distances might be used to select genetically diverse and superior genotypes. Intercrossing of genotypes from these diverse clusters may result in wide array of variability for having effective selection for these characters.

\section{References}

Badade, D.S., S.D. Warade and S.K. Gaikwad. 2001. Correlation studies in bottle gourd. J. Maharashtra Agric. Univ., 26(1): 020022.

Deepa Devi, N and S. Mariappan. 2013. Studies on genetic diversity in snake gourd (Trichosanthes anguina L.). African $J$. Agric. Res., 8(42): 5221-5225.

Dora, D.K., G.C. Acharya, S. Das and T.K. Behera. 2003. Numerical taxonomic approach- a better alternative for clustering of pointed gourd genotypes. The Orissa J. Hort., 31(2): 76-79.

Karuppaiah, P., P. Kavitha and P. Senthil Kumar. 2005. Correlation and path analysis in ridge gourd [Luffa acutangula (Roxb.) L.]. Crop Res., 29(3): 490-494.

Khatun, M., M.G. Rabbani and E.H.M.S. Rahaman, 2010. Estimate of genetic diversity in Snake gourd (Trichosanthes cucumerina). Bangladesh J. Agric. Res., 35: 95-100.
Kumar, S., S.P. Singh and S. Kumar. 1998. Correlation and path analysis for certain metric traits in bottle gourd [Lagenaria siceraria (Mol.) Standl.] Veg. Sci., 25: 41-42.

Mahalanobis, P.C. 1936. On the generalized distance in statistics. Proc. of National Academic Sci. (India), 2: 79-85.

Prasad, V.S.R.K. and D.P. Singh. 1997. Genetic analysis in Parwal. (Trichosanthes dioica Roxb.). Indian J. Pl. Gen. Resour., 10(1): 91-96.

Rameshkumar, S. 2011. Genetic improvement of local brinjal (Solanum melongena L.) types for yield and quality. Ph.D., (Hort.) Thesis, Tamil Nadu Agric. Univ., Madurai.

Reshmi, J. and I. Sreelathakumary. 2011. Multivariate based marker analysis in ash gourd. Indian J. Hort., 68(3): 345-350.

Sanwal, S.K., R.K. Yadav, O.P.K. Singh and N. Rai. 2008. Variability and genetic advance studies in indigenous chow chow genotypes of Northeast India. Indian J. Hort., 65(2): 167-170.

Singh, A.K., R.S. Pan and P. Bhavana. 2013. Heterosis and combining ability analysis in bitter gourd (Momordica charantia L.). The Bioscan, 8(4): 1533-1536.

Singh, D.K., S.K. Maurya, H.R. Jaiswal and Singh. 2008. Studies on genetic variability and genetic advance analysis in ridge gourd [Luffa acutangula (Roxb.) L.]. Prog. Hort., 40(2): 149-154.

Singh, S. and T. Lal. 2000. Assessment of genetic analysis in muskmelon (Cucumis melo L.) J. Res. Punjab Agric. Univ., 37(1-2): 3641.

\section{How to cite this article:}

Alli Rani, E., P. Jansirani and Kannan Bapu, J.R. 2017. Assessment of Breeding Potential of Ridge Gourd [Luffa acutangula (roxb.) L.] Germplasm for Growth, Yield and Quality Using Diversity $\left(\mathrm{D}^{2}\right)$ Analysis. Int.J.Curr.Microbiol.App.Sci. 6(3): 128-133. doi: https://doi.org/10.20546/ijcmas.2017.603.014 